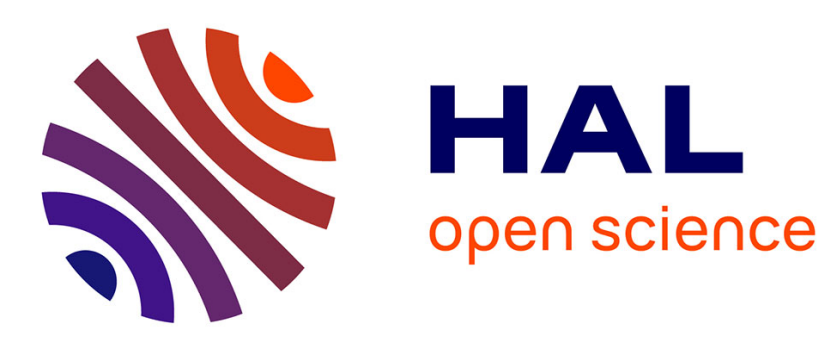

\title{
Hierarchy: a short history of a word in Western thought
}

Nicolas Verdier

\section{- To cite this version:}

Nicolas Verdier. Hierarchy: a short history of a word in Western thought. Pumain D. (ed), Hierarchy in Natural and Social Sciences, Springer, pp.13-37, 2005. halshs-00005806

\section{HAL Id: halshs-00005806 \\ https://shs.hal.science/halshs-00005806}

Submitted on 29 Nov 2005

HAL is a multi-disciplinary open access archive for the deposit and dissemination of scientific research documents, whether they are published or not. The documents may come from teaching and research institutions in France or abroad, or from public or private research centers.
L'archive ouverte pluridisciplinaire HAL, est destinée au dépôt et à la diffusion de documents scientifiques de niveau recherche, publiés ou non, émanant des établissements d'enseignement et de recherche français ou étrangers, des laboratoires publics ou privés. 


\section{Hierarchy: a short history of a word in Western thought}

Nicolas Verdier

CNRS

nicolas.verdier@parisgeo.cnrs.fr

\section{Between the $14^{\text {th }}$ and $17^{\text {th }}$ century, a slow shift of the word outside the sphere of theology}

Usage of the word hierarchy dates back a considerable time. It seems to have been coined by Pseudo-Dionysius the Areopagite ( $6^{\text {th }}$ century AD). It is made up of hieros "sacred" and arkhia "rule". The first clear meaning arises from this etymology, since hierarchy at that time is "the governance of things sacred". As a theological term, it is used to refer to the "subordination that exists between the different choruses of angels. There are nine choruses of blessed spirits divided into three hierarchies" ${ }^{1}$. The word appears to remain in the field of the description of the order and subordination of the different choruses of angels until the $14^{\text {th }}$ century. The concept of hierarchy then enters the register of the description of the ecclesiastical state, and more generally that of society overall. With respect to the clergy, hierarchy is "the subordination that exists between the Prelates and the other ecclesiastics, the Pope, the Archbishops, the Bishops, the Curates and the Priests [who] constitute the hierarchy of the Church" 2 .

One of the contexts where the transition occurs is in works with a strongly religious content. Descriptions of the Creation - which should be viewed as being related to universal mythology- use this mode of exposition. It enables the description of a system of interdependent degrees or ranks of beings and things from the most to the least pure. The metaphor involved is that of the ladder (with its rungs) rising vertically. Samuel Ward, in his "Life of Faith" published in 1622, writes of this system as extending "from the mushrome to the Angels" 3 .

Another context of transition is the cosmograhic style, which uses the heritage of medieval geography and goes on, at the start of the $16^{\text {th }}$ century, to link the celestial globe to the terrestrial globe. Thus P. Apian's Cosmographicus Liber published in 1524 shifts imperceptibly from the celestial spheres to the terrestrial sphere. Apian states that "this science [cosmography] first considers the Circles, of which we imagine the supreme celestial Sphere to be composed. Thereafter, according to the distinction and distribution of the said circles, it declares the situation of the lands which are below them, and the measure and proportions of the same" ${ }^{4}$. Moving on from a merely vertical construction, cosmographic systems point to relationships between the hierarchies of the angels and those of the earth seen as an inhabited world. In this way, hierarchy, which incorporated the poles of the highest and best on the one hand and the lowest and most uncouth on the other, is extended to include the largest and the smallest : here the visual representation used in cosmography leads on to the construction of a more complex concept, in some ways related to the armillary spheres.

\footnotetext{
${ }^{1}$ A. Furetière, Dictionnaire universel contenant généralement tous les mots françois..., La Haye et Rotterdam, Arnout \& Reinier Leers, 1690.

${ }^{2}$ A. Furetière, Dictionnaire... op.cit.

${ }^{3}$ Samuel Ward, The life of Faith in death, 1622, cité dans C. A Patrides, « hiérarchy and order », in Ph. P. Wiener (ed.) Dictionary of the history of ideas, New-York, Charles Scribner's sons, 1973.

${ }^{4}$ P. Apian Cosmographie universelle, Anvers, 1581, p. 5, édition française de Cosmographicus liber, Landshut, 1524, cité par J.-M. Besse, Face au monde, Atlas, jardins, géoramas, Paris, Desclée de Brouwer, 2003, p. 61.
} 
Book 5 of Milton's Paradise Lost, which revolves almost entirely around the concept of hierarchy, witnesses a reunion of these two modes of representation. Milton refers to "the scale of nature set from centre to circumference". Here the inter-relationship of the spheres is seen as a relationship of "alimental" dependency in which the coarser elements enable the purer elements to exist :

"The grosser feeds the purer, Earth the Sea, Earth and the Sea feed Air, the Air feeds those Fires

Ethereal, and as lowest first the Moon;

Whence in her visage round those spots, unpurg'd

Vapours not yet into her substance turn'd.

Nor doth the Moon no nourishment exhale

From her moist Continent to higher Orbes.

The Sun that light imparts to all, receives

From all his alimental recompence

In humid exhalations, and at Even

Sups with the Ocean” 5

The last context of transition that requires mention is at the heart of the discord between Protestants and Catholics. For Luther, neither the Pope nor the bishops nor any man has the right to impose "even one syllable" on a Christian. In other words, all the faithful are priests by their baptism. The Catholics on the contrary put emphasis on the idea that the clerical hierarchy was established by Jesus Christ himself. It is at this time that tensions focus on the question of hierarchy in the clergy, and Catholics resort to the texts by Pseudo-Dionysius the Areopagite denouncing the heresy ${ }^{6}$. According to this author there are two worlds : that of pure intelligence and that of incarnate intelligence. The first constitutes the celestial hierarchy, and the second the ecclesiastical hierarchy. For Pseudo-Dionysius, hierarchy is "a sacred order and science and operation assimilable, as far as attainable, to the likeness of God, and conducted to the illuminations granted it by God, according to capacity, with a view to the Divine imitation" 7. It is at the time of the Council of Trent (between 1545 and 1563) that the word hierarchy was officially adopted to describe the different degrees of the ecclesiastical state. Indeed, the $23^{\text {rd }}$ session of the Council pronounced an anathema on those who opposed the idea of a hierarchy among the clergy : "Si quis dixerit, in Ecclesia catholica, non esse hierarchiam, divina ordinatione institutiam, quac constat episcopis, presbyteris et ministris, anathema sit" ${ }^{8}$. Behind this defensive declaration certainly lay the fear of a secularisation of the clergy which would de facto place the concept of hierarchy outside the religious sphere.

\footnotetext{
${ }^{5}$ John Milton, Paradise lost, A poem un twelve books, The second edition revised and augmented by the same author, London, Printed by S Simmons, next door to the Golden Lion in Aldergste-Street, 1674, book 5, I. 415-425.

${ }^{6}$ Sur Pseudo-Denys l'Aréopagite, on lira R. Roques, L'univers dionysien, structure hiérarchique du monde selon le PseudoDenys, Paris, Cerf, 1983 (1ere éd. 1954).

${ }^{7}$ Pseudo Denys l'Aréopagite, Hiérarchie céleste, Paris 1865, traduction J. Dulac, Chapitre III, § 1.

${ }^{8}$ B. Dolhagaray, "hiérarchie", in A. Vacant, E. Mangenot et E. Amann, Dictionnaire de théologie catholique contenant l'exposé des doctrines de la théologie catholique, leurs preuves et leur histoire, Paris, Libr. Letouzey et Ané, 1925, t. 6.
} 


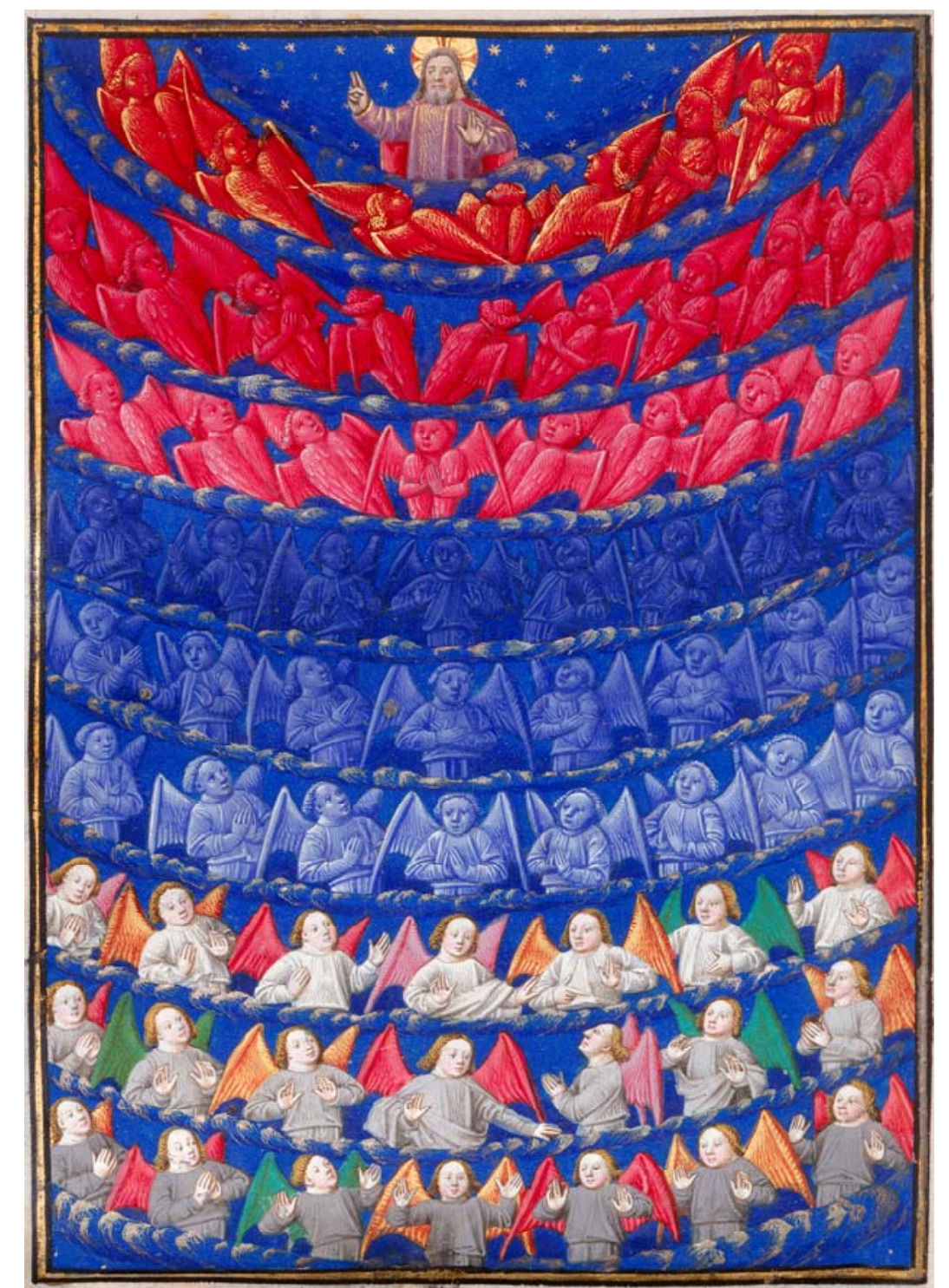

Figure 1: Vincent de Beauvais, Miroir historial. Speculum historiae 1463, BNF. Cliché Bibliothèque nationale de France, Paris

Thus it clearly appears that in Europe at the end of the $17^{\text {th }}$ century the usage of the word hierarchy had shifted from a limitedtheological register to other registers outside the field of theology, at the same time undergoing certain alterations.

\section{The 18th century : from the Hierarchy to hierarchies.}

The writings of Spinoza, Descartes, Leibnitz and Hume, when approaching the concept of hierarchy, question the older conceptions either by broaching the issue of infinity, or by replacing certain levels by others. However, it seems more fruitful to look at more fundamental questionings of the concept of hierarchy as it was seen up to the $17^{\text {th }}$ century, involving on the one hand the presence of God, and on the other the replacement of static 
conceptions of the universe by dynamic conceptions ${ }^{9}$. With respect to the divine presence, it can be noted that in the middle part of the $17^{\text {th }}$ century, Pascal, in a clearly deistic view, was still writing : "I cannot forgive Descartes: he would gladly have left God out of his whole philosophy. But he could not help making Him give one flip to set the world in motion. After that he had no more use for God." ${ }^{10}$. As Spinoza wrote in his Ethica (around 1670) : "Whatever is, is in God, and nothing can be, or be conceived, without God" ${ }^{11}$. It is with the Enclyclopédie produced by Diderot and d'Alembert, however, that conceptions change radically : hierarchy appears as an essentially human construction:

"Hierarchy: is said of the subordination between the different choruses of angels that serve the Almighty in heaven. Saint Denis differentiates nine, which he divides up into three hierarchies [...]; also refers to the different orders of the faithful that make up Christian society, from the Pope, who is the head, down to the mere layman [...]. In civil society there are different orders (ranks) of citizens rising one above the other, and the general and particular administration of things is distributed in portions to different men or classes of men, from the sovereign who rules everyone down to the mere subject who obeys." 12

Thus, according to the Encyclopédie, it is St Denis who distinguishes the different hierarchies, it is Christian society that makes up the hierarchy, and it is the citizens that build the hierarchy of civil (lay) society.

On the issue of the arrival of dynamic conceptions of the universe at the start of the $18^{\text {th }}$ century, the work by Noël Pluche can be quoted. In his "Spectacle de la nature" (1739) he states that the number of plants and animals created by God is fixed: "The number and origin of organised species, as elementary natures, has therefore not been given over to any movement, nor any blind power. One infinitely careful hand has fixed them and they are unchanging, as is the Almighty who has made them" ${ }^{13}$. Here the scale of nature is therefore a continuous line, valid since creation. However in 1765 Voltaire's "Dictionnaire Philosophique" sets out a definition of the "chain of beings". He sees it as being full of gaps: "the proof is that there are species of plants and animals that have been destroyed. There are no longer any Murex. Jews were forbidden to eat griffon or ixion; these two species have probably disappeared from the Earth [...]. Lions and rhinoceros are becoming very rare. If the rest of the world had done as the English did, there would be no more wolves in the world [...]. Is there not a visible gap between monkeys and men? Is it not easy to imagine a twolegged animal without feathers, intelligent but without speech, and without our likeness....?"14. He also sees this chain of beings as made up of incommensurable elements: "But there is a greater distance between God and his most perfect creatures than between the Holy Father and the dean of the Sacred College. The dean may become a pope, but the most perfect genii created by the Supreme Being cannot become God. Between him and God lies infinity." In other words hierarchy (the word is used by Voltaire) does not exist : "this graduation of beings from the smallest atom to the supreme being, this scale of the infinite, strikes wonder. But if one looks closely, this great phantom vanishes, as all ghosts were wont to flee at the first cock-crow" ${ }^{15}$. While the $16^{\text {th }}$ and $17^{\text {th }}$ centuries saw the shift of the concept

\footnotetext{
9 S. J. Miles, "From being to becoming: Science and Theology in the Eighteenth Century", Perspectives on Science and Christian Faith, 43/4, Dec. 1991, pp. 215-224.

${ }^{10}$ Pascal, Pensées, 194.

${ }^{11}$ Spinoza, Éthique, Proposition XV.

12 Encyclopédie, vol 8, p. 205.

${ }^{13}$ Antoine, Pluche, Histoire du ciel, où l'on recherche l'origine de l'idolatrie et les méprises de la philosophie sur la formation, et sur les influences des corps célestes, Paris, chez la Vve Estienne, 1740 (1ere éd. 1739), vol. 2 , p. 362.

${ }^{14}$ Voltaire semble connaître précisément les travaux de Pluche, et certaines hypothèses récentes vont jusqu'à proposer d'en faire le Pangloss du Candide. Sur ce point : E. Palmer, "Pangloss Identified", French Studies Bulletin, 84, Automn 2002.

${ }^{15}$ Voltaire, Dictionnaire philosophique, 1765, article "Chaîne des êtres".
} 
of hierarchy from the sacred to the profane, the $18^{\text {th }}$ century, because it undermined the concept of a unified hierarchy, widened its application, hitherto restricted to certain domains. However it is important to note the wide variability of timings, since it was only in 1835 that the Dictionnaire of that venerable institution, the Académie Française added an entry to the definitions relating to the angels and the clergy, extending the concept to other "sorts of power, authority, and rank subordinated one to another: political hierarchy, hierarchy of power, military hierarchy..."16. In comparison, very early on, the definition of "gerarchia" in the Diccionario de la legua castellana in 1732 puts forward the lay usage of the concept, the definition of the word beginning as follows :

"Gerachia : El orden y subordinacion que en qualquiera Republica bien ordenada, tienen las diversas classes de sugétos que la componen : comme en la Eclesiastica los Prelados superiores è inferiores, il los Clérigos; en la secular les Principes, senores, nobles y plebeyos". ${ }^{17}$

In this way the Spanish Academy positions the ecclesiastic hierarchy on the side of application rather than on the side of principle. Examples of what must be seen as a secularisation of the notion of hierarchy are more widespread in natural sciences, as for instance in Linnaeus and the taxonomy of organisms, or Buffon who believed in the imperceptible evolution of one being into another ${ }^{18}$. They are moreover not the only instances that can be called upon. Indeed, it is clear that these descriptions of nature served as models or even metaphors - for numerous descriptions of society in both the $18^{\text {th }}$ and the $19^{\text {th }}$ centuries. References to the "nature" of society are well known. It therefore seems worthwhile considering other instances which, while they belong to the scope of what were later to become the social sciences from the $20^{\text {th }}$ century onwards, nevertheless contribute to understanding how conceptions evolved. Thus for the period of interest it is possible to focus on the issue of towns and cities, and the hierarchies applied to them which, for a period, organised social hierarchies.

At the end of the $15^{\text {th }}$ century, or even into the $16^{\text {th }}$ century, cities ${ }^{19}$ are immobile. Throughout Europe from one country to another, two or three founding myths are superposed to explain their origins. The first, which is omnipresent, is antiquity. The city is suspended in time and its origins are virtually immemorial. Thus as late as the start of the $18^{\text {th }}$ century the city of Nîmes in France is presented by Piganiol de la Force as having been founded in the "year of the world 2715"; for Chartres, also in France, "if the local tradition is to be believed, it dates back to times very close to the Deluge" ${ }^{20}$. In Italy in 1579, Paolo Paruta, reflecting on what makes up a city, suggests a classification of towns and cities in which superiority is given to the Città according its antiquity: "Since virtue requires outside witness of honour, one

\footnotetext{
${ }^{16}$ Dictionnaire de l'Académie française, 1835.

17 Real Academia Española, Diccionario de la lengua castellana, en que se explica el verdadero sentido de las voces, su naturaleza y calidad, con las phrases o modos de hablar, les proverbios o refranes, y otras cosas convenientes al uso de la lengua..., Madrid, Imprenta de la Real Academia Española, por los herederos de Francisco del Hierro, 1734, Tomo quarto, p. 47 .

${ }^{18}$ Sur ce point, on verra Jean Ehrard, L'idée de nature en France dans la première moitié du XVIIle siècle, Paris, SEPVEN, Paris, 1963, pp. 181-198.

19 Translator's note : there is only partial overlap in French and English of the meanings of words used to designate human settlements, (cité, ville, bourg, etc versus the English city, town, borough, etc) for obvious historical, cultural and chronological reasons. In translation the fairly general acceptations of the words « town » (a settlement of some size) and « city » (suggesting status and a degree of antiquity and privilege) are used. These terms are in no way used to refer to a definite status. (See on this score PJ Cornfield, the introduction to The impact of English Towns 1700-1800, OUP 1982)

${ }^{20}$ Piganiol de la Force, Nouvelle description de la France, dans laquelle on voit le gouvernement général de ce royaume, celui de chaque province en particulier et la description des villes, maisons royales, châteaux et monuments les plus remarquables, avec la distance des lieux,..., Paris, T. Legras fils, 1718, vol IV p. 139 et vol V, p. 299.
} 
considers dignity, and, dignity being equal, antiquity” ${ }^{21}$. The second founding myth concerns the walls, and this idea is found in most of Europe except for Italy, for which country a foreword to Ortelius's Theatrum orbis terrarum (added by the Italian editor) specifies:

“Solamente s'avertisce, chen'paesi oltramontani (Northern Europe) si tengono per Città tutte les Terra murate, che hanno grandezza, e privilegio di Città tutte le que in Italia non si dà communemente questo iotolo fuor che a quei luoghi; che tengono il Vesequo" ${ }^{22}$.

In this foreword to the work by Ortelius, it can be seen that land within walls is essentially city. On this subject, another passage from Piganiol de la Force describes St Etienne (in France) as follows: "It was only a "bourg" (small town) when the inhabitants obtained permission from king Charles VII to surround it with walls". Thus it is the royal consent (or charter) that creates the difference, and this indeed is the third criterion: the granting of a privilege. In his Corografia Portugueza in 1706, Antonio Carvalho da Costa thus hierarchises human settlements into at least four levels:

"In this book your majesty will see a number of cidades, which he has generously endowed with a charter, with many sumptuous buildings, made safe by unassailable fortifications; villas, which he has enhanced with privileges; lugares which he has raised to the rank of villas; and those for which he has enlarged the termos (boundaries)...”23

This ancient hierarchy among human settlements belongs to the ancient model of the hierarchy in which each level corresponds to a particular sphere. It reaches well beyond the mere issue of urbanity, since it entails an extremely efficient system of social classification. This is even more marked in Italy until the end of the $18^{\text {th }}$ century, and in Hungary probably as late as 1848, where the citizen (city-dweller) enjoys a social status that sets him apart from the rest of the population, and can even go as far as to confer statutory nobility ${ }^{24}$. In the words of Bartolo da Sassoferrato in 1570: "It is noteworthy that it is better to be a mediocre citizen of a noble and honourable city than to be a more illustrious citizen of a mediocre town. And this is true for the populares of a noble city, who are to be honoured more than the great men of another town” 25 .

This first period in the hierarchy of human settlements ends around the start of the $18^{\text {th }}$ century, and new modes of classification gradually appear, retaining rather hybrid forms at least until the early $19^{\text {th }}$ century. It is useful to briefly recall how criteria used to describe cities and towns evolved. Initially, as seen above, it was antiquity, walls and privileges that enabled comparisons between cities and towns; then definitions evolve in and around the $18^{\text {th }}$ century towards definitions that put emphasis on urban functions and population. Underlying this trend, there is basically an undermining of the static approach, in favour of a dynamic, historicist approach incorporating notions of evolution and fluctuation. At the same time an approach based on measurement takes over in the $18^{\text {th }}$ century for comparing human

\footnotetext{
21 Paolo Paruta, "Della perfezione della vita politica", Venetia, Nicolini, 1579, cité dans Marco Folin, "Hiérarchies urbaines/hiérarchies sociales: les noms de ville dans l'Italie moderne (XIV-XVIIle siècles)", Genèses Sciences sociales et histoire, $\mathrm{n}^{\circ} 51$, juin 2003, pp. 4-25, (le texte de Paruta est traduit en français dès 1582).

${ }^{22}$ Ortelius, Abraham, Theatro del mondo : enel quale distinctamente si dimostrano in tavole, tutte la provincie, regni \& paesi des mondo, Venetia, il Turrini, 1655, avertissement.

${ }^{23}$ Antonio Carvalho da Costa, Corografia Portuguesa e Descripçam Topografica do Famoso Reyno de Portugal, com as noticias das fundações das Cidades, villas \& lugares que contem..., Lisboa, 1706, tome 1, Prologue, cité par Claudia Damasceno-Fonseca, Pouvoirs villes et territoires, Genèse et représentations des espaces urbains dans le Minas Gerais (Brésil), XVIIle-début du XIXe siècle, Paris, EHESS, 2001, p. 335.

${ }_{24}$ Gabor Czoch, "Réflexions sur les catégories de recensements, l'exemple des bourgeois de la ville de Kassa (Hongrie), 17881847)", Cahiers du centre de recherches historiques, oct. 1996, n¹7, pp. 193-198.

${ }^{25}$ Bartolo de Sassoferrato, In tre codicis libros, Venezia, Giunti, 1570, cité dans D. Quaglioni, "The legal definition on Citizenship", in A. Molho, K. Raaflaub, J. Emlen, City-states in Classicla Antiquity an d Medieval Italy: Athnes, and Rome, Florence and vencie, Ann Arbour, University of Michigan Press, 1991, pp. 97-140.
} 
settlements, in connection with the study of economic functions or populations. As Bernard Lepetit writes: "With movement comes measurement, an absolute need if evolutions in different directions and of variable intensity are to be taken into account" ${ }^{26}$. The result of this evolution can be clearly seen in the following description of the town of Saint Quentin (France): "Its manufacturers, its workshops, the trading activity and the industry of its inhabitants make it one of the best towns in France" 27.

Two examples of attempts to hierarchise towns and cities are worth considering here to highlight classification processes other than those encountered in natural sciences.

The first example comes from Robert de Hesseln who, in his Dictionnaire Universel de la France, in the article entitled "France", differentiates between the first-ranking towns comprising 100000 inhabitants, second-ranking towns comprising "nearly 40000 or 50000 inhabitants", the "bonnes villes" of the third rank with no more than 20000 inhabitants, "a large number of towns with 8000, 10000 and 12000 inhabitants", and an "infinite number of small towns". Thus on the one hand the quantification of the number of inhabitants makes it possible to establish a hierarchy among human settlements, while on the other the viewpoint of continuity in the distribution among these different settlements shows that levels of urbanity are not really commensurable. The system at once accepts the principle of a common measure for all types of settlement, and at the same time, as in the past, distinguishes clearly separate levels.

The second example of attempts at hierarchisation of towns and cities, from the work by Charles de Fourcroy in his Essai de Tableau Poléométrique dated 1782, compares urban surface areas. This surface area criterion in fact corresponds to the ancient manner of considering walled areas which made it possible to define cities according to an enclosed surface area. The disappearance of city walls, already widespread at the end of the $18^{\text {th }}$ century, rendered this type of measurement problematic by the time Fourcroy was writing, the indicator having become obsolete. Conversely, the possibilities of a continuous graduation appear clearly at this stage, if only in the very form of Fourcroy's tableau, even if he suggests a hierarchical organisation into "very small towns", "small towns", "medium sized towns", "large towns" and "very large towns" 28 . The graduation from one category to another is along a continuum which seems quite clearly inherent in the system of representation. At the same time, the use of quantitative demographics de-couples the hierarchy of towns from the social hierarchy. Fourcroy was no longer thinking in terms of a relationship between the quality of the inhabitants and that of the town, he was restricting himself to quantities:

\footnotetext{
${ }^{26}$ Bernard Lepetit, "L'évolution de la notion de ville d'après les tableaux et descriptions géographiques de la France", Urbi, $n^{\circ} 2$, décembre 1979, pp. XCIX-CVII.

${ }^{27}$ Couédic, P., Tableau géographique de la puissance industrielle, commerciale et agricole de la Nation Française, par départements, districts, et cantons, suivant l'ordre de la nouvelle distribution du Royaume, dans lequel on trouve la démarcation des limites de chaque département \& de ses districts, la nature des productions de son sol, son étendue \& sa population...., Paris, rue des Mathurins, 1791, 2 vol, vol. 1, p. 31

${ }^{28}$ Charles de Fourcroy, Essai d'une table poléométrique, ou Amusement d'un amateur de plans sur les grandeurs de quelques villes, Paris, Dupain-Triel père, 1782.
} 


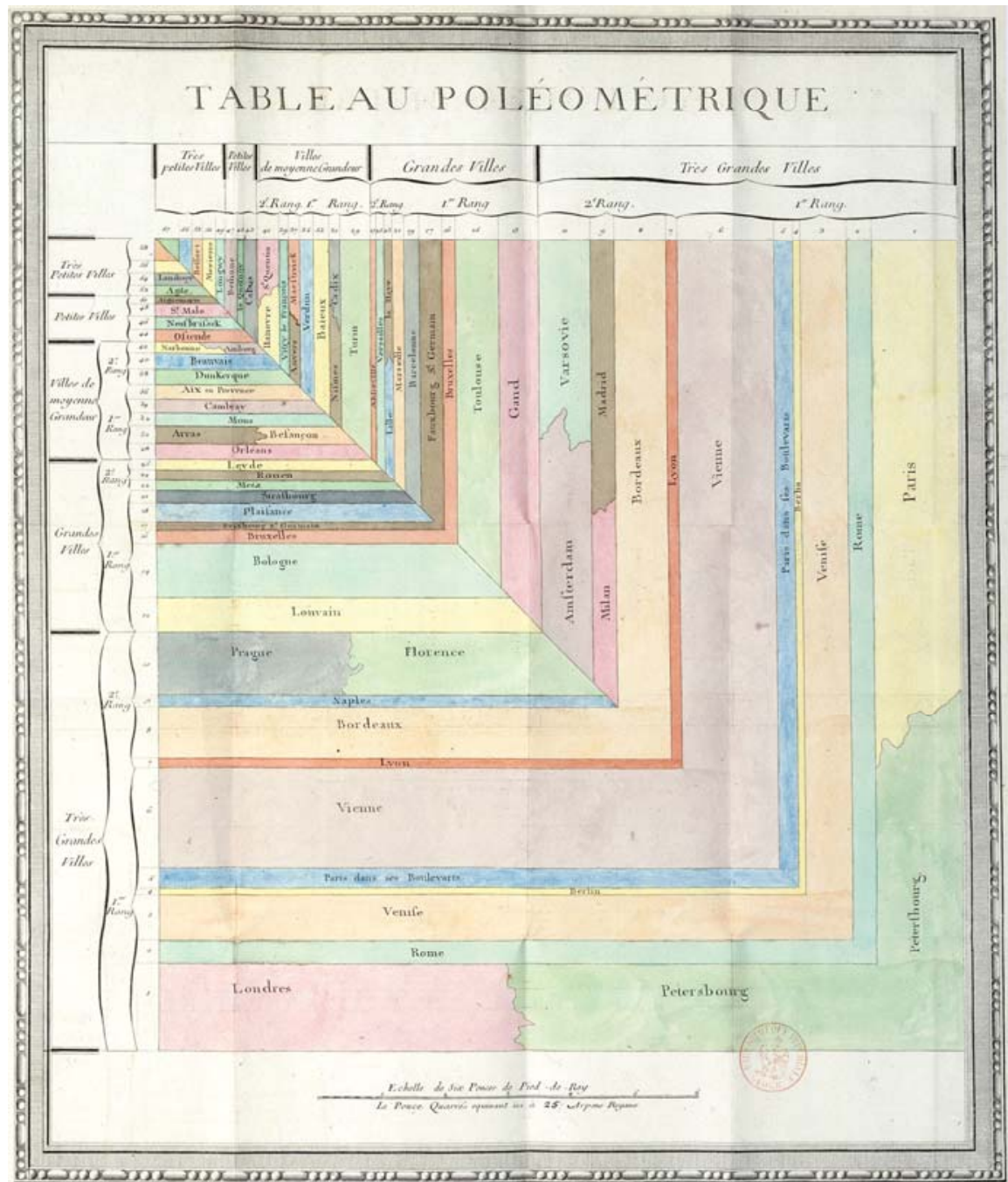

Figure 2: Charles de Fourcroy, Essai d'une table poléométrique, ou amusement d'un amateur de plans sur la grandeur de quelques villes, Paris, Dupain-Triel, 1782. BNF

Cliché Bibliothèque nationale de France, Paris

"Between the surface area of a town and the number of its inhabitants there must be a certain ratio that is more advantageous than any other, or which constitutes the most suitable population which question, to my knowledge, has never been treated, although it relates not merely to curiosity" 29 .

What then remains of the hierarchical classification of society? In fact, the concept is not affected by this separation, since hierarchy appears as a necessary principle in the organisation of society. As Montesquieu wrote in L'Esprit des Lois (1748), "in the state of nature, men are indeed born in a state of equality; but they cannot remain so. Society has them lose this equality, and they only regain it by way of the laws". Even so, this equality before the law is radically altered by inequality in the political sphere. For Montesquieu (who uses the word hierarchy to describe society ${ }^{30}$ ) “ monarch rule [...] assumes pre-eminence, rank,

\footnotetext{
${ }^{29}$ Charles de Fourcroy, Essai d'une table poléométrique...l, p. 24, cité par Gilles Palsky, Des chiffres et des cartes, la cartographie thématique quantitative au XIXe siècle, Paris, CTHS, 1996, p.52.

30 Ainsi, dans ses "Considérations sur la France", Montesquieu décrit la constitution des jury en évoquant le fait que "La hiérarchie des mouvances appelait les vassaux du même ordre dans la cour de leurs suzerains respectifs; de là naquit la maxime que tout homme devait être jugé par ses pairs". Esprit des Lois, livre XI, chap. VIII.
} 
and even original nobility [...], for the prerogatives of the lords, the clergy, the nobility and the towns" ${ }^{31}$ constitute a rein both to excessive power of the prince and to the passions of the people. The view held by Montesquieu, which was to be taken up ten years later in the Encyclopédie, is therefore one of a necessary hierarchy within society. In this way, it is an almost revolutionary conception, since it no longer justifies the existence of the populace by blood rights, but rather by social necessity. This same idea was developed around 1741 by Yves André in his Essai sur le Beau, in which he claims the need for a hierarchy in ranks and orders as being essential to the harmony of the social microcosm ${ }^{32}$. Put in other terms, in another civilisation, the idea is also found in the Koran, according to which "some of us have been raised above the others so that they may take the others into servitude" ${ }^{33}$. In France, this contrast between equality before the law and political equality will be encountered later at the time of the Revolution, which, while it abolished privileges during the night of August $4^{\text {th }}$ 1789 , shortly afterwards instated a system of tax-payer vote ${ }^{34}$.

Overall, it is probably with the disappearance of the Ancien Régime that the concept of social hierarchy really developed, the existence of a word making it easier than previously to apprehend in thought and criticise.

\section{Paradoxes of the first part of the $19^{\text {th }}$ century}

One of the features of the start of the $19^{\text {th }}$ century following propositions that, as seen above, were hybrid and sometimes contradictory, is that there are two simultaneous trends, one restricting and one opening up the usage of the word hierarchy. There is restriction, in that the meaning of the word is frequently narrowed once more, mainly to the area of theology. Thus in the various editions of the dictionaries of the Royal Spanish Academy there is first a reversal of priorities in the definition between 1780 and 1817, the issues of political organisation previously set out as the first entry becoming the last entry, and the meaning of the order and subordination of angels becoming the first. At the same time, the definition which took up some 15 lines is reduced to four. After 1837 political organisation is only a meaning "by extension" of the word. It is only in 1984 that the definition of the word eventually evolves, returning to a more lengthy definition (8 lines), and applying it to a description of the internal organisation of society. The meaning of "an important person within an organisation" is also added, the word here being used to describe the summit of the pyramid. If however the corpus is widened to works that are more open to the contemporary world, evolutions can be seen at an earlier date. Thus in the Encliclopedia universal ilustrada Europeo-Americana, published in Barcelona in 1926, which give translations of words into French, Italian, English, German, Portuguese, Catalan and Esperanto, the word jerarquia boasts three entries, one concerning the administrative hierarchy, the second the ecclesiastical hierarchy and the third the military hierarchy ${ }^{35}$.

Despite this, the diversity of usage of the word hierarchy was greatly reduced in $19^{\text {th }}$ century Spain. Along the lines of this narrowing of usage, it can also be noted that the word does not appear to be in use among English-language economists in the $18^{\text {th }}$ and $19^{\text {th }}$ centuries. For instance, if a search is made for the word hierarchy in Steuart (1767), Smith (1776, and also

\footnotetext{
${ }^{31}$ Montesquieu, L'esprit des lois, livre VIII.

${ }^{32}$ Sur ce point, on se reportera à Jean Ehrard, L'idée de nature en France dans la première moitié du XVIIIle siècle, Paris, SEPVEN, Paris, 1963, pp. 516-540.

${ }^{33}$ Coran, sourate 6, verset 165 (traduction issue de André Jacob (dir.), l'Encyclopédie philosophique universelle, Paris, PUF, 1990, vol. 1, p. 1140.

${ }^{34}$ Mona Ozouf, "Égalité", in François Furet et Mona Ozouf (dir.), Dictionnaire critique de la Révolution française, Paris, Flammarion, 1988.

${ }^{35}$ Enciclopedia universal ilustrada Europeo-Americana, Barcelona, Hijos de J. Espasa Editores, 1926.
} 
the translation into French by Blanqui in 1846), Bentham (1776, 1787, and 1796), Ricardo (1810 and 1817) and finally Mill (1848 and numerous re-editions up to $1886^{36}$ ), no references are found. Moreover it can be observed that the 1911 edition of the Encyclopaedia Britannica provides a definition that is restricted to the mere question of theology. After rapid research it seems possible to say that it is only with Keynes (1919) that the word appears in the writings of an English-language economist ${ }^{37}$. It can be added, outside English language usage, that Das Kapital by Karl Marx, both in its original version and in its French translation, does not use the word hierarchy. Thus the word is absent, while authors like Smith or Marx are generally considered as having contributed to originating the concept of social class which can imply the idea of social hierarchy, as is shown for example in the definition of social hierarchy given in the Encyclopédie Philosophique Universelle published under André Jacob in $1990^{38}$. In other words - and the paradox is worth noting - some of the most prominent authors of the nineteenth century with regard to the issues of social hierarchies do not resort to the word to describe society.

What indeed are the usages of the word in the course of the $19^{\text {th }}$ century, during which it appears to have disappeared at least in part ? First it is important to avoid oversimplification: even if the word hierarchy is not widely used, it is still in existence, one the one hand in the area of theology, which is in no way radically new, and on the other in the description of society, and this is the most relevant aspect here, because it is the most innovatory.

\section{Alexis de Tocqueville: De la démocratie en Amérique}

In this respect, attention can be given first to Alexis de Tocqueville and his book $\mathrm{La}$ Démocratie en Amérique published in France in 1835 and in the United States in 1839 (translated by Henry Reeve). Tocqueville seems to use the word hierarchy in three ways, two with negative connotations and one with mitigated connotations. The first concerns the social hierarchy of the Ancien Régime and its aristocracy. Thus, on the subject of the colonies around 1620, Tocqueville writes:

"The population of New England was growing fast, and, while in the mother country the hierarchy of rank still classified men in a despotic manner, the colony increasingly showed the new spectacle of a society homogeneous in all its parts. Democracy, as Antiquity had never dared dream it, emerged large and well armed from within the ancient feudal society” 39.

The second usage by Tocqueville concerns the administrative hierarchy described as producing perverse centralising effects (book 1 chapter V). The third concerns the natural social hierarchy which arises from the activity of individuals. Here Tocqueville seems indecisive: on the one hand, social hierarchy seems to him to be necessary for civilisation: "One can conceive of a people in which there would be no cast, no hierarchy, no class; in which the law, recognising no privilege, would share out inheritances equally; and which

\footnotetext{
${ }^{36}$ Sur les éditions successives des Principes d'économie politique, on lira M.-A. Ellis, "Variations in the Editions of J. S. Mill's Principles of Political Economy", Economis Journal, vol 16, june 1906, pp. 291-302.

${ }^{37}$ James Steuart, An Inquiry into the Principles of Political Economy, London, 1767 ; Adam Smith, An Inquiry into the Nature and Causes of the Wealth of Nations, 2 volume, London, W. Strahan \& T. Cadell, 1776 ; Jeremy Bentham, A Fragment on Government; being an examination of what is delivered, on the subject of Government in General in the introduction of Sir William Blackstone's Commentaries; with a preface, in which is given a critique on the work at large, anonymous, London, T. Payne, P. Elmsly \& E. Brooke, 1776, Defense of Usury; Shewing the Impolicy of the Present Legal Restraints on the Terms of Pecuniary Bargains. In a Series of Letters to a Friend. To which is added a letter to Adam Smith, Esq. LL.D. on the Discouragements Opposed by the Above Restraints to the Progress of Inventive Industry, London, T. Payne, 1787; Philadelphia, Lang \& Ustick, 1796 ; David, Ricardo, The High Price of Bullion, A Proof of the Depreciation of Bank Notes, London, John Murray, 1810 ; On the Principles of Political Economy and Taxation, London, John Murray, 1817 ; John Stuart Mill, Principles of Political Economy, with some of the their Applications to Social Philosophy, 2 volumes, London, Parker, 1848. John Maynard Keynes, The Economic Consequences of the Peace, London, Mac Millan and co, 1919.

${ }^{38}$ André Jacob (dir.), l'Encyclopédie philosophique universelle, Paris, PUF, 1990, vol. 1, p. 1140

${ }^{39}$ Alexis de Tocqueville, La démocratie en Amérique, (livre 1, chap. II).
} 
would at the same time be deprived of enlightenment and freedom. This is not a vain hypothesis: a despot can have motive to render his subjects equal and leave them ignorant, so as to more easily maintain them in slavery. [...] Not only would a democratic people of this sort have no aptitude or taste for science, literature and the arts, but one could imagine that they never would come to show any" 40 .

In the eyes of Tocqueville, hierarchy is a natural form of society, and absence of hierarchy only appears possible under a rule of tyranny aiming at the ignorance of the people. However, this hierarchy, however natural, is still to be condemned, since it isolates the outsider:

"The North American Indian living in the freedom of the woods was wretched, but felt inferior to no-one; as soon as he wishes to enter the social hierarchy of the white man, he can only occupy the lowest rank; for, ignorant and poor, he enters a society where science and wealth reign. After leading a life of turmoil, full of evils and dangers, but at the same time full of emotions and greatness, he must submit to a monotonous, obscure and degrading existence. The sole result in his eyes of belonging to this much-boasted society is to be earning his bread by drudgery, in the midst of ignominy" ${ }^{4}$.

Finally, what this man (born an aristocrat but conscious of the unavoidable disappearance of his cast) seems to abhor are the superimposed categories with their stereotyped boundaries. There is a last point worth making here concerning usage of the word hierarchy in a military context. Indeed, in the first part of his work, Tocqueville draws a comparison between the world of military officers and that of the nobility in order to show that the two hierarchies are not necessarily similar. In so doing, Tocqueville is no doubt one of the first to use the word in the context of the army.

The wide spectrum of usage found in Tocqueville's writings does not appear among other authors in the same period. There are indeed a few uses of the word hierarchy by a historian (and politician) such as Guizot. In his monumental Histoire Générale de la Civilisation en Europe this author only uses the word when referring to the feudal system, and mainly with respect to the clergy ${ }^{42}$. Usage of the word in these instances refers to the obsolete past. Likewise Marx who, as we have seen, does not use the word in Das Kapital, in the Communist party Manifesto in 1948 only uses a restricted meaning based on a military metaphor to describe modern industry: the workers, "simple soldiers of industry are placed under the supervision of a complete hierarchy of officers and commanders" ${ }^{43}$.

\section{Auguste Comte: hierarchy as a system}

The above instances of usage to describe society are not sufficient to fill the relative void in the first half of the $19^{\text {th }}$ century among authors that can in some way be connected with the social sciences of the future. The de-Christianisation of the "republic of letters", as well as the egalitarian ideals that flood across Europe after the French revolution, certainly have considerable influence. But an alternative explanation for this relative absence may reside in a more general manner of apprehending the organisation of formal (disciplinary) areas of knowledge into an all-encompassing system of knowledge. It indeed may be appropriate to reposition the evolution of the term of interest here in the context of the questioning of encyclopaedic knowledge. Indeed, in the $18^{\text {th }}$ century, hierarchy relates essentially to a type of approach that is liable to produce a global model for understanding the world. The $19^{\text {th }}$

\footnotetext{
${ }^{40}$ Alexis de Tocqueville, la démocratie en Amérique, (livre 2, section 1, chap. IX).

${ }^{41}$ Alexis de Tocqueville, la démocratie en Amérique, (livre 1, chap. X).

${ }^{42}$ François Guizot, Histoire générale de la civilisation en Europe depuis la chute de l'empire romain jusqu'à la Révolution française, Bruxelles, lacrosse Libr.-Éd., 1838.

${ }^{43}$ Karl Marx et Freidrich Engels, Manifeste du parti communiste, Londres, février 1848.
} 
century is on the other hand an intermediate period in that it is the time of transition between "encyclopaedism" and disciplinary constructs involving restricted fields of knowledge in which hierarchies (rather than any one Hierarchy) will serve as explanatory principles. Thus it is possible to suggest that the usage of the word is in proportion to the degree of autonomy of the discipline to which an author belongs. Conversely, the demise of Hierachy should be sought in the last genuinely encyclopaedic experiments, or those aiming at least to think in terms of a rational organisation of knowledge.

From this point of view Auguste Comte and Positivism are very relevant. Indeed Auguste Comte was the creator of the neologism sociology ${ }^{44}$, and he placed this science at the summit of his classification of knowledge. In his view, it is the science that, on its own, enables understanding of knowledge as a whole, organised in the form of an encyclopaedia. Indeed, Comte points to his use of the term hierarchy in his Cours de philosophie positive, where he states: "I use this expression purposely to emphasise that I cannot conceive of a genuinely philosophical classification if one has not first managed to apprehend a predominant consideration [hierarchy], common to all instances, and gradually decreasing from one [science] to the other. It [hierarchy] is, in my view, the fundamental condition imposed by the general theory of classifications" 45 .

Comte uses the idea of encyclopaedic degrees, or even of an encyclopaedic scale or ladder, emphasising the progression of one science to another. This leads him to "instate moral science proper on the seventh necessary degree in the encyclopaedic hierarchy, to complete the normal progression of complication and specialisation" ${ }^{46}$ existing among the sciences. This does not prevent him perceiving a genuine continuum among these same sciences. In his view, each science is at least in part at once sovereign and subordinate. "There are undoubtedly today certain methods in chemistry or physiology that it would be useful to transfer to mathematics, and vice versa; this is not done, and the question is why ? The reason is that each scholar is busy advancing his own particular science, and does not think of extracting and giving assistance to other scholars, nor of looking for it from them” 47 .

There should not therefore be any strict divide between the sciences. However the limits to such exchanges should be specified. Thus Comte strongly criticises the "algebraic usurpation" which suggests that mathematics can enable understanding of phenomena that are in fact rendered complex by the wide diversity of approaches required to comprehend them. This is why he refuses to take an interest in Condorcet's "social mathematics" and his use of probabilities in the study of votes ${ }^{48}$. It is along these lines and for the same reasons that he criticises the work by Franz Joseph Gall on phrenology which used the shape of the cranium as a basis for a philosophy of the human mind ${ }^{49}$.

The conceptions entertained by Comte on the hierarchy of sciences are all the more complex because he initiates a transition between hierarchised knowledge and equality among the sciences. Indeed, for Comte, this hierarchisation is merely functional: it enables him to analyse the general system of knowledge. At the same time, the sciences are seen to be equal one to the other in terms of status: "Although all fundamental sciences do not generate the

\footnotetext{
${ }^{44}$ Auguste Comte, $47^{\mathrm{e}}$ leçon de son Cours de philosophie positive, vol 1, 1837.

${ }^{45}$ Auguste Comte, $46^{\mathrm{e}}$ leçon du Cours de philosophie positive, vol 1., 1837

${ }^{46}$ Auguste Comte, Système de politique positive, (1851-1854) (vol. 2).

${ }^{47}$ Lettre à Valat, 24 sept. 1819 (A. Comte, Correspondance générale, op. cit. n. 2, t. 1, p. 59-60) cité dans Annie Petit, "Des sciences positives à la politique positiviste", in Auguste Comte. Trajectoires du positivisme, Paris, L'Harmattan, 2003.

${ }^{48}$ Sur ce point, on verra Laurent Fédi, Comte, Paris, Les Belles Lettres, 2000, pp. 66-69.

49 Franz Gall, Darstellung der Nerven, auf Untersuchungen desVerrichtungen des Gehirns gegründeten, Theorie des Physiognomik, Weimar, 1802.
} 
same interest among vulgar minds, none should be neglected in a study such as the one in hand. As for their importance for human happiness, all are certainly of equal value, when they are examined closely. Indeed, those in which results at first sight present a lesser practical interest recommend themselves clearly, either by the greater perfection of their methods, or by being the essential foundation of all the others" ${ }^{50}$.

Comte's view of hierarchy is therefore more complex than the views seen hitherto, since it dissociates the value and the function of the elements making up the hierarchy. It seems justifiable here to suggest a genuine "comtian" model for the hierarchical organisation of knowledge. But rather than a branching hierarchy, often derived from his classification of the positive sciences, it seems more appropriate to refer to a pathway model for knowledge. This model, placing the "positive sciences" one after the other in the construction of the ultimate science, i.e. sociology - or the study of man - re-uses the ancient model of the "chain of beings", from the most simple to the most complex, while at the same time attributing the same value of necessity to each component.

\section{The second part of the $19^{\text {th }}$ century : spread or scatter?}

\section{The Durkheim hierarchy: a relational social model}

One of the most interesting features of Comte's production for this study of the word hierarchy probably resides in the idea of a statutory equality among positive sciences, at a time when disciplines were becoming institutionalised, an increasing tendency all through the last half of the $19^{\text {th }}$ century. Indeed, it would appear that in the years following these last attempts at institutionalisation, although the word hierarchy certainly does not disappear from usage, there is a relative absence of discussion of the concept, as if the spread of the word rendered it more labile.

The spread of usage in France is indeed quite clear. A rapid review of the catalogues of the Bibliothèque Nationale gives around 330 different titles containing the word hierarchy between the start of the $16^{\text {th }}$ century and the end of the $20^{\text {th }}$ century. Of the 34 listed between 1800 and 1850, 26 relate to religious questions and 5 to military questions. For the following period, 1851 to 1900, there are 35 references, but only 16 of these concern religion. The 5 pertaining to military matters remain, but there are now 6 references relating to administrative organisation (against 1 in the previous period), 6 relating to the description of society and 2 relating to the hierarchy of laws one to the other. It should however be noted that in the same period in works in English language in the Congress library, usage remains in the religious sphere until as late as 1936.

Thus the spread of the different forms of usage is restricted in the Western world to the "old continent". Reference can be made here to Emile Durkheim who can be considered as one of the founders of sociology. Durkheim practically never uses the word hierarchy. It is found in three instances in his "Division du travail social (1893) and five times in Le suicide (1897), but it is not found either in Les règles de la méthode sociologique (1894) or in Les formes élémentaires de l'organisation sociale (1904).

To gain a better understanding of the usage of the word in Durkheim it can first be noted that the word is never defined by the author. It should also be noted that a word such as "graduation" does not occur any more frequently than hierarchy, so that it is not a question of choice of term. Durkheim does mention the question in his article in 1900 in the Rivista

\footnotetext{
${ }^{50}$ A. Comte, Cours de philosophie positive, vol. I, 1ère leçon
} 
italiana di sociologia ${ }^{51}$, in which he discusses the idea of demonstrating how hierarchies form by looking for those features that social forms have in common to produce hierarchy. However, he only takes a real interest in the question in the article co-authored with Marcel Mauss on the primitive forms of classification ${ }^{52}$. The authors put emphasis not so much on the act of classification as on the historical nature of the concept and its non-natural aspects, which leads them to consider the issue of hierarchy: "Classification is not a mere matter of forming groups, it is positioning groups according to very special relationships. We see them as being coordinated or subordinated one to the other, we state that these (the species) are included in these (the genera), that the second subsumes the first. There are those that dominate and those that are dominated, and others that are independent one from another. Any classification implies a hierarchical order for which neither the perceptible world nor our awareness can supply a model”.

At the end of the article, the authors conclude: "It is because human groups fit one into the other [...] that groups of objects are set out in the same order. Their regularly decreasing extension as we pass from genus to species, from species to variety, etc, arises from the likewise decreasing extension presented in social divisions as one moves away from the widest and most ancient towards the most recent and derived. If all things are conceived as a single system, it is because society is conceived in the same manner. It is [...] the single whole to which all else is referred. Thus logical hierarchy is merely another aspect of social hierarchy and unity of knowledge is nothing other than the very unity of the community, extended to the universe".

Following a functionalistic approach, which sees society as a systemic whole made up of subgroups which are so many organs involved in reproducing of the whole, Durkheim excludes the hierarchy of key concepts from the reasoning, replacing it by inter-relation between the elements. It can also be added that his determination to remain abstract, in an endeavour to distinguish general social forms - which he intends to construct from shared features of the objects under study - restricts the interest he shows in actual relationships in society as they are practised. The hierarchy of practice is replaced by a functional model of interrelationships.

The conceptions of Simmel are from this point of view fairly close to those of Durkheim, and this appears clearly in his attempt to define Sociology ${ }^{53}$. The main difference probably lies in the interest Simmel has for forms of socialisation, which he studies in a very subtle manner ${ }^{54}$. But here again it is more a study of functional relationships than a study of hierarchies.

Once again, hierarchy remains on the side of generalities and can up to a point be taken to be a synonym of the word "society" as these authors seem to view it. By concentrating on narrower themes, they exclude hierarchy as such from the framework of study, using the word but ultimately avoiding using the actual concept.

\section{Sigmund Freud: an attempt to go beyond the hierarchy of a functional whole}

Even though the work of Freud is mainly positioned in the $20^{\text {th }}$ century, it may be interesting to refer to it here in order to move beyond the often disappointing features of the study of the concept of hierarchy in the period extending from the Franco-Prussian war in 1870 to the

\footnotetext{
${ }^{51}$ E. Durkheim, "La sociologia e il suo domino scientifique" in Rivista italiana di sociologia, 4, 1900, pp 127-148

52 É. Durkheim et M. Mauss, "De quelques formes de classification - Contribution à l'étude des représentations collectives". Année sociologique, VI, (1901-1902), pp. 1 à 72.

${ }^{53}$ G. Simmel, "Le problème de la sociologie", Revue de métaphysique et de morale, 1894, 6eme année, pp. $497-504$.

${ }^{54} \mathrm{G}$. Simmel, Soziologie. Untersuchungen über die formen der vergesellschaftung, Leipzig, Duncker \& Humblot, 1908
} 
years between the two world wars in the $20^{\text {th }}$ century. From the point of view of the history of disciplines, it is possible to consider that this period is fairly relevant, since it is during this time that the scientific disciplines of the human and social sciences form and consolidate in Europe, mainly via the creation of university chairs.

Attention will be given here to a single text by Freud published in French in 1921 under the title "Psychologie collective et analyse du moi" ${ }^{55}$. If it is the only text chosen for analysis it is merely because it is the only one to use the word under consideration ${ }^{56}$. It is also one of the texts taking the most interest in collective issues. Freud's attempt to hierarchise the phenomenon of love into degrees on the basis of the analysis of language - ending in a distribution into degrees from the most to the least libidinal - however suggests no hierarchy of the degrees one with respect to the other. The most productive passage from the point of view of the present study appears to be the comparison between the two hierarchies of the army and the Church (which he appears to restrict to Protestantism). For Freud, "a democratic force pervades the Church because all are equal before Christ, since all have an equal right to his love" which he qualifies as fatherly. However, "from the point of view of structure the Army distinguishes itself from the Church in that it is made up of a hierarchy of successive formations : each captain, like the commander in chief, is the father of his company, each officer is the father of his division". What Freud notes here is one of the foundations of the differentiation among hierarchies. In the first instance, we can see the old system of the spheres, on the one hand Christ who loves all men, and men who must love one another in order to love Christ: the two levels are essentially different. In the second instance, in the Army, there is a descending relationship from one level to the next which ensures transfer of the libidinal bond of fatherhood, without this bond changing in nature. Thus Freud shows that with the same explicative principle (the libidinal bond of fatherhood) it is possible to obtain two types of hierarchy that are essentially different. By producing this reasoning, which is in fact fairly close to Durkheim, what Freud does in addition is to change the scale of observation by shifting from a family principle (fatherhood) to social construction by hierarchy. Here hierarchy is not an assumption, it is a product. It would seem moreover that it is this transition, between Durkheim and Freud, from the social to the collective, that enables the shift. It can be noted here that this renewed usage of the collective concept enables Maurice Halbwachs in the 1930s to study the production of memory as a collective form ${ }^{57}$.

\section{Conclusion}

From the above set of examples, although it is neither exhaustive nor adequate to constitute an overview of the usages of the concept of hierarchy, in instances where a concept can indeed be identified via the use of a word, it is even so possible to attempt the definition of the four main lines of variation of the concept.

The first point that it seems important to stress is that of the range or scope of the concept : in extreme instances it can explain the whole universe, as with Apian or Milton, or perhaps society as a whole with Durkheim; conversely can be strictly limited to a clearly outlined object, as with Pseudo Dionysius, or with Marx who uses it solely to describe the military system.

\footnotetext{
${ }^{55}$ S. Freud, "Psychologie collective et analyse du moi" publié dans l'ouvrage Essais de psychanalyse. Traduction de l'Allemand par le Dr. S. Jankélévitch en 1921, revue par l'auteur. Réimpression : Paris : Éditions Payot, 1968, pp. 83 à 176.

${ }^{56}$ Sur ce point, on consultera http://www.uqac.uquebec.ca/zone30/Classiques_des_sciences_sociales/

${ }^{57}$ M. Halbwachs, La mémoire collective, Paris, PUF, 1950 (éd. Posthume).
} 
The second point to be emphasised is the contrast between continuity and discontinuity. Freud thus appears to view the military system as a continuity of the libidinal bond of fatherhood, where differences in degree or rank in no way affect the nature of the hierarchic bond. Conversely, Voltaire, like Milton, considers that the shift from one level to another constitutes so large a change that the different hierarchical ranks are strictly incommensurable.

The third point to be made - possibly that which is the most relevant to human and social sciences, is that of the status given to the concept. Tocqueville provides two contrasting examples. In the first, hierarchy is synonymous with despotism (and this became a widely shared acceptation in Europe in the 1960s), and in the second it is what endows a civilisation with its intellectual wealth, which is at least partly related to the Koran sura 6 verse 165.

This leads on to the final point concerning the nature of hierarchy. By nature, what is meant here is the place given to hierarchy in reasoned thought. The two extremes set the proponents of a hierarchy that is to be discovered (such as Buffon and much of the writing on nature in the $18^{\text {th }}$ and $19^{\text {th }}$ century, or even the exponents of social Darwinism) against the proponents of an elaboration of a hierarchy by researchers in a given area (as in the definition given in l’Encyclopédie).

Each of the cases presented above needs to be considered in this four-dimensional system, the positioning within one or other of these dimensions having no impact on the positioning in any of the other three. It can also be recalled that contradictions or different registers in usage in the writings of one and the same author are quite possible, as for instance with Tocqueville.

Appendix: Developments in the second part of the $20^{\text {th }}$ century

Figure 1 Frequency of the word hierarchy in book titles 


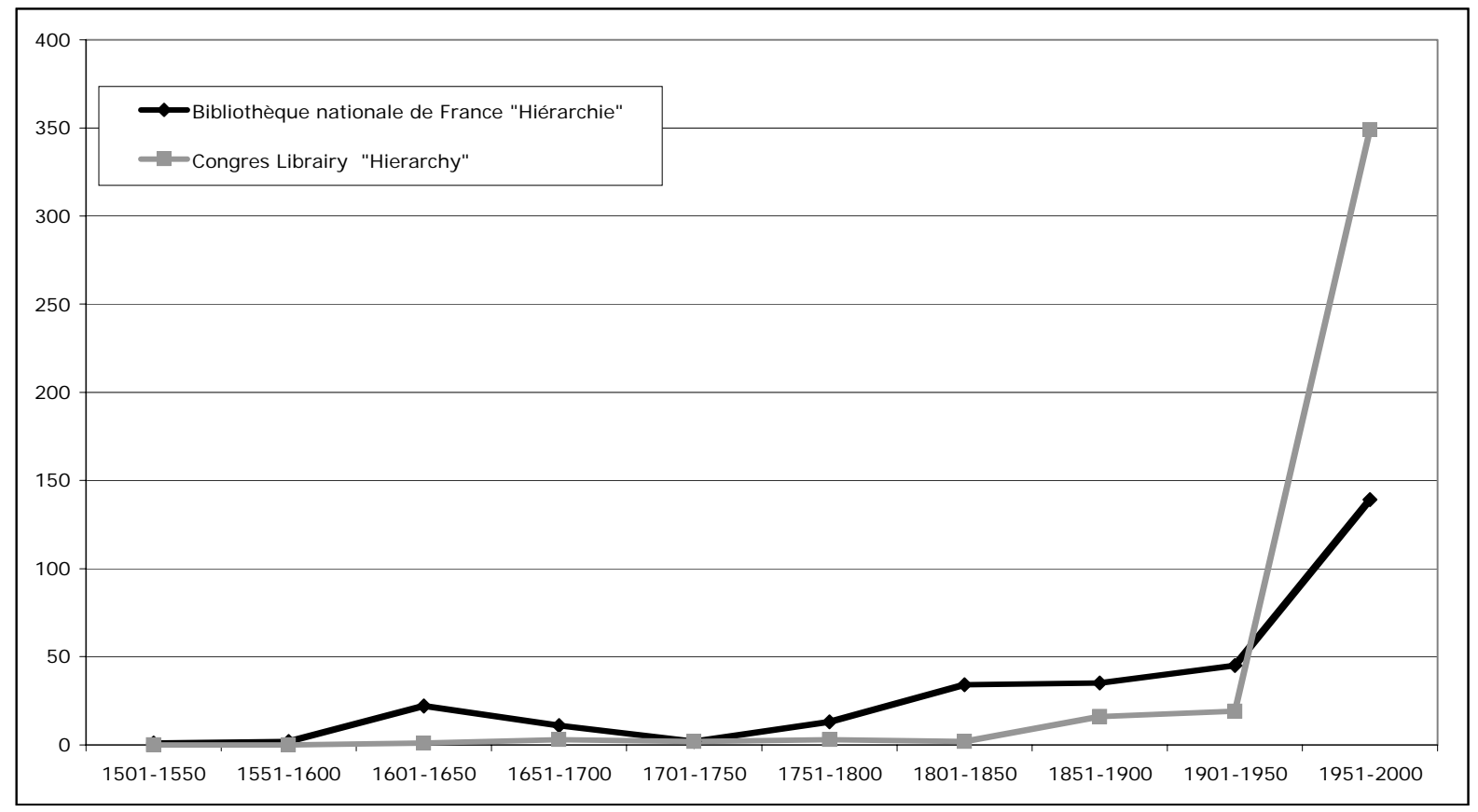

Finally the most recent forms of usage of the word hierarchy can be mentioned. In this respect, one of the most noteworthy aspects is its spread at the end of the 1930s, first in relation to questions of society, in some cases resulting in deviations such as those already noted in the work by Franz Joseph Gall, whose successors are to be found in Germany in the ruins of the Prussian military state and elsewhere, whether among geographers like Christaller $^{58}$, or among Nazi theoreticians. This probably also explains the disgrace of the word in the years directly after the 1939-45 war. It is not until the 1960s that the word reappears in social sciences. Thus it appears in American sociology with T. Parsons and P.Sorokin ${ }^{59}$, but the subject matter is often closer to the notion of stratification than to that of hierarchy. The question of hierarchy is also encountered in French anthropology with the work by L.Dumont on casts ${ }^{60}$. A less well-known instance should also be noted, on the frontiers between geography (which is a social science in France) and geology, that of Jean Tricart who, on the basis of the new theories on erosion cycles, went on to complexify the concept of hierarchy by linking it to that of scale. Thus this author, linking what he terms "temporo-spatial hierarchies" to scales of analysis, proposes a model to apprehend erosion cycles which links up phenomena occurring at different levels from the continent down to the slope (scree). Thus scale appears clearly as belonging to the question of hierarchy in the 1950s. The same author returns to these principles in analyses of urban geography.

\footnotetext{
58 W. Christaller, Die zentralen Orte in Süddeutschland. Eine ökonomisch-geographische Untersuchung über die Gesetzmässigkeit der Verbreitung und Entwicklung der Siedlungen mit städtischen Funktionen, Jena, Gustav Fischer, 1933.

${ }^{59}$ T. Parsons, Essays in sociological theory, Glecoe, Free Press, 1949 ; P Sorokin, Social and Cultural Mobility, Glencoe, Free Press, 1959.

${ }^{60}$ L. Dumont, Homo hierarchicus. Le système des castes et ses implications. Paris, Gallimard, 1966
} 